\title{
EDITORIAL
}

\section{Travessias: Memória, ClíNICA E Cultura}

Denise Maurano

Joana Souza

Renata Mattos Avril

Com muita alegria, abrimos esta edição trazendo seção de artigos temáticos, que versa sobre a temática da memória, da voz, da música e das musicalidades em psicanálise, três instigantes artigos que abrangem com pertinência o cruzamento entre psicanálise e cultura. Em consonância com a Edição Especial de Psicanálise \& Barroco em Revista sobre o tema "Psicanálise e Política: versões e reversões do mundo e do imundo" lançado no mês de Outubro deste ano, abrimos este número com um escrito do psicanalista Jean-Michel Vivès que é, ao mesmo tempo, uma reflexão profunda sobre a incidência da voz - em sua vertente superegóica - em diferentes correntes políticas autoritárias e, principalmente, um convite, um chamado, à criação de outras saídas e escolhas possíveis que confirmem a dimensão desejante dos sujeitos.

É assim que em "Não havia outra escolha possível": conformismo, conformidade e confirmação. Uma abordagem psicanalítica do devir-desistente ou do devir-persistente", Jean-Michel Vivès propõe uma análise do contexto político brasileiro atual a partir de suas raízes na História da humanidade e, sobretudo, a partir do interior do posicionamento do psicanalista e de sua escolha ética de dar espaço à voz. A voz em sua singularidade radical, a voz que se autor-iza na polifonia do mundo. O autor faz, deste modo, uma diferenciação entre três posições subjetivas distintas, a saber, o conformismo, a conformidade e a confirmação, para localizar o que, na constituição subjetiva, concerne a todos os sujeitos e que se apresenta como um obstáculo à escuta da diferença e da invocação originária da voz do Outro em seu enigmático "Che vuoi?", "Que queres?".

A ausência estrutural de uma resposta à esta pergunta pode colocar o sujeito tanto numa posição de um devir-desistente quanto de um devir-persistente. No primeiro caso, o conformismo a uma "outra voz", que buscar fazer "Uma voz" e silenciar a diferença, se instala. Já no segundo, o vazio é escutado em sua dimensão 
de criação e de confirmação do desejo. O que poderia ser traduzido, parafraseando Freud, em: "lá onde a voz do Outro invocava, eu devo advir me autor-ziando como voz desejante que improvisa com os outros". A versão em francês desse precioso texto, também consta neste número.

No artigo "Consonâncias e dissonâncias nos modos de escuta na música e na psicanálise", a musicóloga, antropóloga e etnomusicóloga Olga Picún se alia à psicanalista Ana María Fernández Caraballo para refletir sobre os efeitos das mudanças de paradigmas estéticos e estilísticos no Modernismo na forma de escuta da musicalidade tanto no campo da música quanto no da subjetividade através da psicanálise. Partindo da questão sobre como a psicanálise de Freud e Lacan se interessaram pela questão da música e do sonoro, as autoras nos levam a rememorar e percorrer as propostas subversivas do campo musical face à tradição ocidental do tonalismo e de sua tendência à consonância. Fazendo um paralelo entre a ruptura com o saber da época que tanto Freud quanto o compositor Schönberg propuzeram, ambos em Viena, e a produção na cultura de um espaço para a escuta daquilo que atua no humano da ordem do inconsciente, as autoras apontam que o que se coloca em cena a partir daí é a escuta de uma escrita do sujeito que está no mais-além da representação, que inclui, assim, a dissonância.

Num viés fundamentalmente clínico e em diálogo com a teoria, a psicanalista Fernanda Mara da Silva Lima nos presenteia em seu artigo, "A voz no tratamento psicanalítico das psicoses", com uma nova proposta de escuta e de trabalho com crianças autistas. Para tanto, a autora parte das elaborações teóricas de Lacan e de autores lacanianos sobre a voz e a musicalidade na constituição subjetiva, enfatizando os impasses que podem se apresentar no autismo quanto à alienação à voz do Outro. A proposta aqui é a de, respeitando as diferenças estruturais entre neurose e psicose, aprender com os passos teóricos já dados na psicanálise em relação ao objeto voz para que a prática clínica com crianças autistas possa Ihes oferecer um manejo face a este objeto, demasiadamente próximo nestes casos, de modo a se criar uma distância. A autora nos traz, assim, uma bela vinheta clínica em que uma menina autista e sua mãe são escutadas em suas singularidades diante da voz, podendo ao longo do tratamento psicanalítico Ihes dar um outro destino.

Dando continuidade, abrimos a seção de artigos livres com o artigo de Luciano Lima de Oliveira e Laéria Fontenele intitulado "Entre Priapo e Dionísio: reflexões 
sobre a masculinidade", onde interrogam a masculinidade e o por que da necessidade que dela procede de dominar a feminilidade. Para pensar essa questão, os autores retomam a hipótese da bissexualidade psíquica construída por Freud para mostrar que masculino e feminino são posições que os sujeitos ocupam na busca por satisfação pulsional, e por isso não se vinculam à logica nos gêneros. A hipótese dos autores é de que essa necessidade de dominação da feminilidade relaciona-se ao horror do homem relativo a seu próprio desejo de feminilidade; que o angustia e o ameaça desde o interior. Em seguida, temos o ensaio "Um pranto utópico: travessias de um infantil alienante" de autoria de Marcos Pippi de Medeiros e Edson Luiz André de Souza, no qual retomam o livro "História do Pranto", de Alan Pauls, para pensar a questão do infantil e a alienação que lhe é característica como condição para nossa inclinação ao sonho utópico.

Talita Alcântara Fontenele e Silva e Henrique Riedel Nunes, descrevem no trabalho "Psicanálise e residência na rua: situando lugares (im)possíveis", uma rica experiência em torno do acompanhamento junto a população de rua do projeto chamado "Residência na Rua: Saúde, Cultura e Arte", onde residentes realizam abordagens noturnas junto à população de rua do centro de Fortaleza/CE. Os autores procuram elucidar os modos de atuação extramuros do psicanalista através de experiências artísticas. Em "Dor e gozo na psicanálise: uma revisão", Patrícia do Socorro Nunes Pereira, Roseane Freitas Nicolau e Jamile Luz Moraes Monteiro discorrem a acerca da relação entre a dor e a uma forma de gozo que Lacan nomeou como fora-da-linguagem, chamado também de gozo Outro. Segundo atestam, esse gozo é inacessível às palavras e comparece para o sujeito na compulsão à repetição, estando, portanto, vinculado ao masoquismo primário, como indicou Freud. Objetivando conceituar o afeto do ódio na obra freudiana, Joelma Galvão de Lemos no texto "O que Sigmund Freud nos fala sobre o ódio?", faz um interessante caminho teórico no sentido de depreender o porque é mais fácil para o homem fazer uso do discurso de ódio, chegando até a direcionar atitudes agressivas e violentas no convívio com o outro.

Em "O estatuto da interpretação em psicanálise", Ricardo Brandel Junior e Denise Maria Lopes Dal-Cól, mostram como o nascimento da psicanálise se relaciona com a descoberta do inconsciente e sua relação com o sintoma. Para os autores, a interpretação na psicanálise é corolária do conceito de inconsciente, por isso seu 
manejo é fundamental para a direção da cura. Na mesma direção, apresentamos o artigo "O corpo uma palavra amordaçada: da clínica psicanalítica ao âmbito da saúde mental" escrito por Camila de Freitas Moraes e Rudimar Mendes, que discorre sobre o lugar representativo do corpo do louco e seu emudecimento pela via da medicalização, o que desemboca na exclusão do próprio sujeito. Os autores destacam o lugar de resgate que a psicanálise pode ocupar no tratamento das psicoses na rede de saúde mental. Fechamos a seção com o trabalho "O padrão corporal feminino no balé: uma leitura psicanalítica", de autoria de Moema Fiuza de Campos e Kátia Alexsandra dos Santos que analisam as implicações da formação para o balé clássico na relação da bailarina com seu corpo, levando em conta a constituição da imagem corporal para o sujeito, a partir dos pressupostos psicanalíticos.

Por fim, temos a brilhante resenha "Quando o ponto surdo não ensurdece e outras notas musicais e psicanalíticas" escrita por Lucas Emmanoel Cardoso de Oliveira, a partir da leitura do livro "Variações psicanalíticas sobre a voz e a pulsão invocante" de autoria de Jean-Michel Vivès. Lucas destaca a noção de ponto surdo, referido a um lugar intrapsíquico, correlato ao recalque originário, onde o proto sujeito, após ter entrado em continuidade com a voz primordial, tornou-se surdo a esta voz, se tornando um sujeito do inconsciente que fala sem saber o que diz e com uma voz singular diante das múltiplas vozes que lhe constitui.

Assim, convidamos a todos os que se interessam pelas temáticas abordadas nessa edição uma excelente leitura. Até a próxima!!!

(C) 2019 Psicanálise \& Barroco em revista

http://www.seer.unirio.br/index.php/psicanalise-barroco/index

revista@psicanaliseebarroco.pro.br

Programa de Pós-Graduação em Memória Social — UNIRIO

Memória, Subjetividade e Criação

www.memoriasocial.pro.br/proposta-area.php 